\title{
Development of a fish-based index of biotic integrity (FIBI) to assess the quality of Bandama River in Côte d'Ivoire*
}

\author{
B.R.D. Aboua ${ }^{(1)^{* *}}$, E.P. Kouamélan ${ }^{(1)}$, V. N'Douba(1) \\ Received June 17, 2011 \\ Revised January 29, 2012 \\ Accepted January 31, 2012
}

\section{ABSTRACT}

Key-words: habitat quality, freshwater fish, biotic index, bandama River, Côte d'Ivoire
The aim of this study was to develop effective tools based on fish assemblages, allowing the development of an effective assessment approach for the ecological status of running waters. Fish samples were collected using gill-nets with mesh sizes of $8,10,12,14,15,18,20,25,30,35,40$, $45,50,55,60,65,70,75$ and $80 \mathrm{~mm}$. Forty sites were visited from October 2008 to September 2009 in the Bandama River. A large part of the data set on fish descriptors associated with environmental parameters was compiled from regional databases. For each of the fish assemblage descriptors, stepwise multiple linear regressions with habitat variables were carried out. The residuals of the models obtained were used as candidate metrics independent of natural environmental factors. Student $t$-tests used to compare each metric in reference and disturbed samples indicated significant difference $(P<0.05)$ for six metrics. The standard residuals of metrics selected were added to constitute the final index. This multimetric index of fish assemblage integrity could serve as a practical technical reference for conducting cost-effective biological assessments of lotic systems.

\section{RÉSUMÉ}

\section{Développement d'un indice d'intégrité biotique basé sur le poisson pour évaluer la qualité du fleuve Bandama en Côte d'Ivoire}

\begin{abstract}
Mots-clés : qualité de l'habitat, poissons d'eau douce, indice biotique, fleuve Bandama, Côte d'Ivoire

Le but de cette étude était de développer un outil basé sur le peuplement de poissons qui permettrait une évaluation effective du statut des cours d'eau. Les poissons ont été récoltés à l'aide de filets maillants de maille : $8,10,12,14,15,18,20,25$, $30,35,40,45,50,55,60,65,70,75$ et $80 \mathrm{~mm} .40$ sites ont été visités durant un an (octobre 2008 à septembre 2009) sur le fleuve Bandama. Une grande partie des données sur les descripteurs de poissons, associée aux paramètres environnementaux, a été fournie à partir d'études déjà réalisées en Afrique. Pour chacun des descripteurs des peuplements de poissons, des relations ont été établies avec des variables environnementales, à partir de régressions linéaires multiples pas à pas. Les résidus de ces modèles ont été utilisés comme métriques susceptibles d'entrer dans la constitution d'un indice. Le test-t utilisé pour comparer les métriques entre prélèvements perturbés et prélèvement non perturbés indiquent une différence significative $(P<0,05)$ pour six métriques. Les résidus standards des métriques
\end{abstract}

(1) Laboratoire d'Hydrobiologie, UFR Biosciences, Université de Cocody, 22 BP 582, Abidjan, 25, Côte d'Ivoire. * The study was carried out by the Hydrobiology Laboratory of the Cocody - Abidjan University (Côte d'Ivoire)

** Corresponding author: abouabrd@yahoo.fr 
sélectionnées ont été additionnés pour constituer l'indice final. L'indice multi-paramétrique obtenu devrait être capable de fournir une évaluation pertinente de la qualité écologique des hydrosystèmes fluviaux.

\section{INTRODUCTION}

Human perturbations in river ecosystems lead to the deterioration of water quality and aquatic habitats (Allan and Flecker, 1993). Ivorian streams are subject to many disturbances. Indeed, the discharge of industrial effluents (Boubo, Sassandra, etc.), the use of fertilizers and pesticides in large plantations near running waters, the construction of hydro-agricultural and agro-pastoral dams (Go, Bandama, San Pedro, etc.) and hydroelectric dams (Bia, Bandama, Sassandra) have perturbed normal assessment of ecosystems (Gourène et al., 1999; Da Costa et al., 2000; Koné et al., 2003; Kouamélan et al., 2003; Kouamé et al., 2008). Moreover, the introduction of species to improve small-scale fisheries, develop fish farming or for biological control (Gooré $\mathrm{Bi}$, 2009) can affect the biological functioning of ecosystems through food chains. Hocutt et al. (1994) summarized that all water resource development projects on the African continent have either failed to meet their stated objectives, and/or had sociocultural and ecological impacts that were not predicted beforehand. In Côte d'Ivoire, deforestation estimated at $375 \mathrm{~km}^{2}$. million ${ }^{-1}$ capita (Lévêque and Paugy, 1999) resulted in the extinction of some fish species (Kamdem Toham and Teugels, 1999; Kouamélan, 1999). Given that these various threats affect aquatic environments, an assessment of water quality was necessary to preserve aquatic resources. It has been noted that the physical and chemical environment of a river is deeply influenced by the characteristics of the environment from which it flows; but the measurements in the water column refer to the conditions prevailing in the course at the time of collection. This led to the monitoring of river integrity using biological communities (fish) by Karr (1981). These reflect the usual or extreme events that have occurred in the past up until this moment in the studied areas. Fish assemblages are reckoned as indicators of aquatic ecosystem health, which has become key in water quality management (Karr, 1981; Karr et al., 1986; Oberdorff et al., 2002; Tejerina-Garro et al., 2006; etc.). In this context, guilds of fish are useful for both understanding aquatic community ecology and giving sound advice to decision-makers by means of metrics for indices of biotic integrity. The index of biotic integrity (IBI) could be a potentially useful management tool for the conservation of the species and their habitat. According to Kamdem Toham and Teugels (1999), development of a fish IBI for African rivers is favored by the naturally high species richness, compared with rivers of the temperate regions. However, the fish IBI application is made difficult because of the lack of biological community data and life-history information on most West African species, and the scarcity of information concerning fish community changes in response to environmental degradation in our streams. In the Bandama River, these statements hold true, but must be moderated. Generally, the biology, ecology and systematics of the species are not known as well as in temperate regions. Nonetheless, fish remains the best-known group of purely aquatic African animals (Daget and Iltis, 1965; Planquette and Lemasson, 1975; Mérona, 1981; Teugels et al., 1988; Traoré, 1996; Paugy et al., 2003a, 2003b; etc.). According to Hugueny et al. (1996), in West Africa, ecological and systematic knowledge are sufficient to meet the needs of an IBI based on fish assemblages. Good identification keys exist (Paugy et al., 2003a, 2003b). Fish biotopes and diets based on the index of preponderance of food items are generally known (Natajaran and Jhingran, 1961; Paugy, 1994; Fishbase, 2003).The objective of our work was to develop an index that would express system responses in Bandama River on a spatial scale that would help to target management of non-point sources of pollution. This approach consists of integrating environmental factors acting on fish assemblage structure under natural conditions, and distinguishing humaninduced disturbances from natural variations. There are two possible approaches to establish the metrics of IBI. The first approach consists of using metrics or descriptors already defined in other studies (e.g. other Fish IBI studies) that have been proven to identify perturbations. 
The second approach consists of selecting the metric for our data, which discriminate reference sites and disturbed sites. But in this latter case, the IBI must be validated on new independent data; which means that there are enough sites to select the metrics on a part of the data and test on another portion of the data. In this study, the first approach was chosen where metrics sensitive to perturbation were selected.

\section{MATERIALS AND METHODS}

\section{> STUDY AREA}

Bandama River, located entirely in Côte d'lvoire, drains an area of $97500 \mathrm{~km}^{2}$ between $3^{\circ} 50$ to $7^{\circ} \mathrm{W}$ and $5^{\circ}$ to $10^{\circ} 20 \mathrm{~N}$. It is $1050 \mathrm{~km}$ long and rises in the north of the country between Korhogo and Boundiali and enters Grand-Lahou lagoon at sea level (Figure 1). Because of its north-south orientation, it covers different climatic and biogeographic areas. The Bandama river has a low slope gradient all over its course. It is characterized by alternating riffles and rocks (Mérona, 1981; Lévêque et al., 1983). The study zone comprises the main course of Bandama River with two man-made lakes (Kossou and Taabo), and the main tributaries, which are the Marahoué on the right bank $(550 \mathrm{~km})$ and the N'Zi on the left bank $(725 \mathrm{~km})$. The basin was chosen for the homogeneity of its ichthyofauna (Mérona, 1981; Aboua et al., 2010) and because of the existence of identified perturbations, which allows the IBI to be tested in situ. The sampling stations in this study were located on the main channels. They were chosen by considering access facilities and the presence of known human perturbations. At the Sucrivoire site (B34 and B35), in the Marahoué River, $213 \mathrm{~km}$ from the source, the river is characterized by relatively steep slopes and a rocky bottom, and receives discharges from Sucrivoire plant and runoff from sugar cane plantings. At the site B38 (Bouaflé), the river receives discharges from a brewery and lemonade plant. The sampling station B33 (N'Zianouan) on the N'Zi River is characterized by extensive fishing and by diffuse pollution from plantations of banana, papaya, palm tree, rice, etc. The sampling stations Pronoua (B29), Taniakro (B30) and Koyékro (B32) of the same river are located on the small reaches so that flows are interrupted during the dry season to form stagnant waters. On the main course of Bandama River, there are sampling stations located between the hydroelectric dam of Kossou and the hydroelectric dam of Taabo, representing a $95 \mathrm{~km}$ stretch. These hydroelectric dams influence water levels and produce electricity. Upstream of Bandama main channel, the river receives discharge from Sucaf plantations. These dams restrict fish movement, particularly between both dams, in the region upstream of Kossou dam, and in the region downstream of Taabo dam. Other potential inputs to this stretch of the river include tributaries; for example, a major tributary (Marahoué River) which flows into the Bandama river to Bozi (B10). Moreover, there is runoff from agricultural activities as well as smaller municipalities, artisanal goldmining activities in the region downstream of Kossou dam, and extensive fishing to Zambakro (B11). In total, forty sites were classified a priori as reference or disturbed sites. The reference sites were those with no obvious signs of environmental disturbance or those with only minor signs of disturbance. The disturbed sites were those with obvious environmental disturbance from gold mining, dam construction, urbanization, and industrial, agricultural and fishery activities (Table I). The study zone was sampled between October 2008 and September 2009. The samples were collected during high and low water periods. However, due to the natural variability of the rains and the position of the hydroelectric dams on Bandama River, the water fluctuations were minimal and not considered in this study (Hugueny et al., 1996; Berté, 2009).

\section{> ENVIRONMENTAL VARIABLES}

At each sampling site, the following environmental variables were measured at the center of each reach. The physicochemical variables included $\mathrm{pH}$ and temperature (measured using a $\mathrm{pH}$-meter $\mathrm{pH} 300 / 310$ ), dissolved oxygen (oxymeter DO 330/310), conductivity and total dissolved solids (conductimeter CON 400/410), and water transparency (Secchi disk). These 


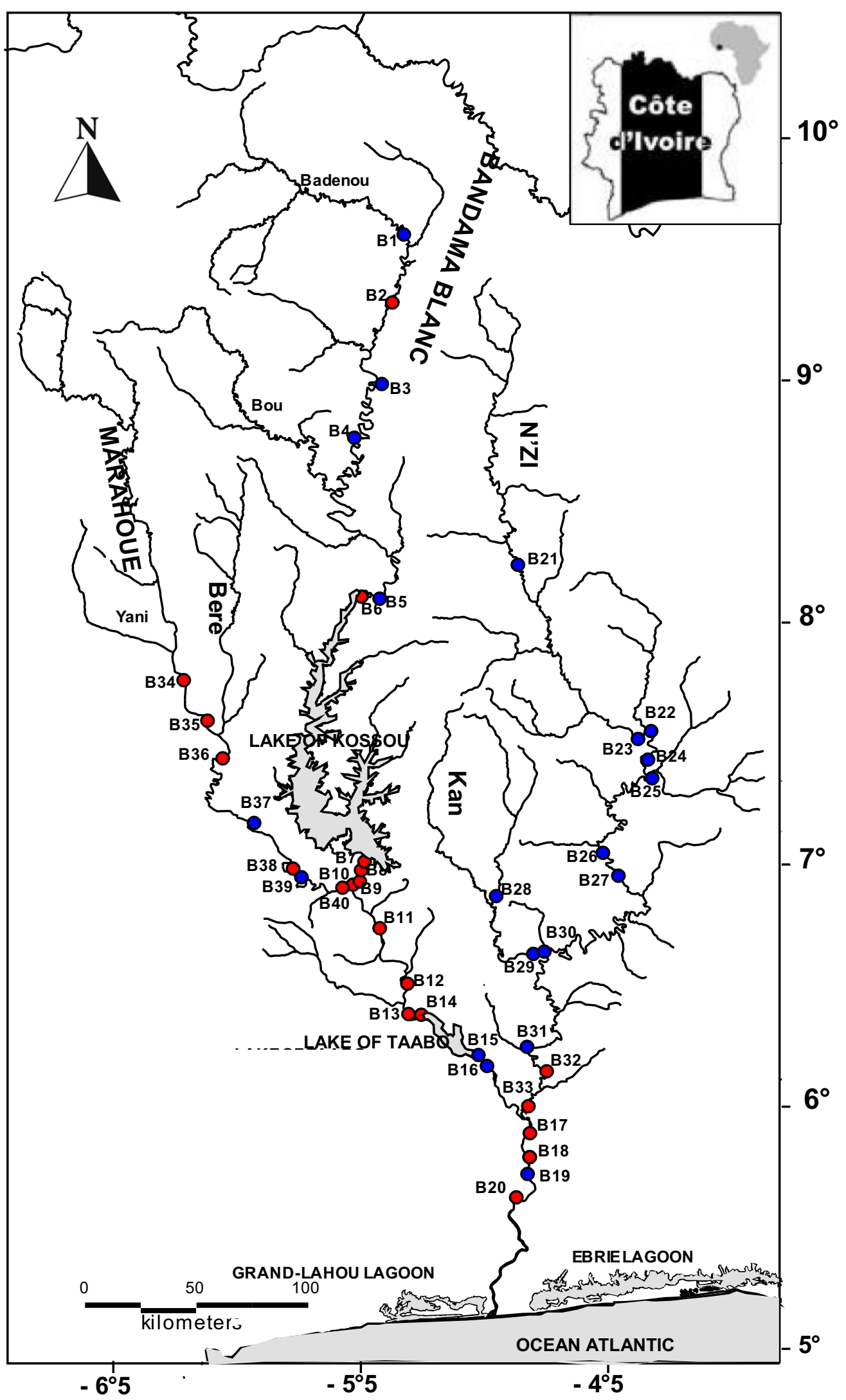

Figure 1

Map of the Bandama River and location of sampling sites. (๑): a priori reference sites, (๑): a priori disturbed sites. 


\section{Table I}

Sites sampled in Bandama river basin. The known or supposed environmental disturbances are indicated. IW: industrial waste, D: dam, GM: gold mining, UR: urban and/or agricultural diffuse pollution.

\begin{tabular}{|c|c|c|c|}
\hline Water course & Stations & Codes & Disturbances \\
\hline \multirow[t]{20}{*}{ Bandama blanc } & Sinématiali & B1 & \\
\hline & Komborodougou & B2 & IW \\
\hline & Longo & B3 & \\
\hline & Nabédjakaha & B4 & \\
\hline & Marabadiassa & B5 & \\
\hline & Bouakaman & B6 & UR \\
\hline & Kossou & B7 & D/GM \\
\hline & Allai-Yaokro & B8 & D/GM \\
\hline & Toumbokro & B9 & D/UR \\
\hline & Bozi & B10 & D/UR \\
\hline & Zambakro & B11 & D/UR \\
\hline & Kimoukro & B12 & D/UR \\
\hline & Beriaboukro & B13 & D/UR \\
\hline & Bonikro & B14 & D/UR \\
\hline & Lamto & B15 & \\
\hline & N'Denou & B16 & \\
\hline & Tiassalé & B17 & IW/UR \\
\hline & Ahua & B18 & UR \\
\hline & Broubrou & B19 & \\
\hline & Bakanda & B20 & UR \\
\hline \multirow[t]{13}{*}{$N^{\prime} \mathbf{Z i}$} & Yékolo & $\mathrm{B} 21$ & \\
\hline & Zaonkro & B22 & \\
\hline & YieraKro & B23 & \\
\hline & Ouokoukro & B24 & \\
\hline & Angouakro & B25 & \\
\hline & Bocanda & B26 & \\
\hline & Dimbokro (N'Zi) & B27 & \\
\hline & Dimbokro (Kan) & B28 & \\
\hline & Pronoua & B29 & \\
\hline & Taniakro & B30 & \\
\hline & Kalékoua & B31 & \\
\hline & Koyekro & B32 & UR \\
\hline & N'Zianoua & B33 & UR \\
\hline \multirow[t]{7}{*}{ Marahoué } & Sucrivoire (SR) & B34 & UR \\
\hline & Sucrivoire (SB) & B35 & UR/IW \\
\hline & Zuénoula & B36 & UR \\
\hline & Zoola Danagoro & B37 & \\
\hline & Bouaflé & B38 & IW \\
\hline & N'Gattakro & B39 & \\
\hline & Bozi & B40 & D/UR \\
\hline
\end{tabular}


Table II

Quantitative and qualitative environmental variables considered for index development.

\begin{tabular}{|c|c|c|c|c|}
\hline Variable & Code & Description & Range & Transformation \\
\hline Flow velocity & VEL & $\begin{array}{c}\text { mean of } 3 \text { measure, } \\
\mathrm{m} \cdot \mathrm{s}^{-1}\end{array}$ & $0-1.63$ & $\log (x)$ \\
\hline Depth & DEP & $\mathrm{m}$ & $0.5-6.5$ & $\log (x)$ \\
\hline Width & WID & $\mathrm{m}$ & $0.5-180$ & $\sqrt{x}$ \\
\hline Canopy closure & CAN & $\%$ & $5-90$ & $\operatorname{Rnd}(x)+C$ \\
\hline Altitude & ALT & $\mathrm{m}$ & $27-984$ & none \\
\hline Watershed area & WSA & $\mathrm{km}^{2}$ & $1200-95500$ & $\log (x)^{2}$ \\
\hline Distance to river source & DistS & $\mathrm{km}$ & $100-947$ & none \\
\hline Slope & SLO & $\%$ & $0.11-1.35$ & $\sqrt{x^{3}}$ \\
\hline \multicolumn{5}{|l|}{ Channel substrate } \\
\hline Sand & SAN & $\%$ & $0-60$ & $\log (x)$ \\
\hline Gravel & GRA & $\%$ & $0-60$ & $\log (x)$ \\
\hline Mud & MUD & $\%$ & $0-35$ & $\log (x)$ \\
\hline Rock & $\mathrm{ROC}$ & $\%$ & $0-90$ & $\log (x)$ \\
\hline Clay-mud & $\mathrm{CM}$ & $\%$ & $0-90$ & $\log (x)$ \\
\hline $\mathrm{pH}$ & $\mathrm{pH}$ & & $6.27-10.45$ & $\operatorname{Rnd}(x)$ \\
\hline Dissolved oxygen & DO & $\mathrm{mg} \cdot \mathrm{L}^{-1}$ & $2.99-7.5$ & none \\
\hline Conductivity & Cnd & $\mu \mathrm{S} \cdot \mathrm{cm}^{-1}$ & $40.5-138.7$ & none \\
\hline Water tranparency & Transp & $\mathrm{cm}$ & $20-213$ & RndNormal $(x)$ \\
\hline Water temperature & $\mathrm{Te}$ & ${ }^{\circ} \mathrm{C}$ & $24.1-32.55$ & none \\
\hline Total dissolved solids & TDS & $\mathrm{mg} \cdot \mathrm{L}^{-1}$ & $21-119.6$ & $\arcsin (\sqrt{ } x / 100))$ \\
\hline
\end{tabular}

variables were measured at 7.00 a.m and 1.00 p.m, except for water transparency, which was measured between 10.00 a.m and 15.00 p.m. Local physical and biological habitat variables were noted, as follows: the channel width (which was measured aboard a boat from one side to the other bank with rope), the channel depth (measured with a graduated weighted rope), the altitude, determined using a GPS (Global Positioning System) 12, Garmin, the current velocity, measured by observing the horizontal displacement of a float over a calibrated distance according to McMahon et al. (1996), mean canopy closure (expressed in \% to the nearest $\mathrm{m}$ ), and substrate type (sand, gravel, rock, mud and mixed clay-mud). Distance from sources and the watershed area were measured using a digital planimeter on a 1/200 000scale map and slope derived from topographic maps. The average value of each variable was computed. These variables were subsequently transformed into a limited number of synthetic variables (Table II).

\section{> FISH SAMPLING AND FISH ASSEMBLAGE DESCRIPTORS}

Fish assemblages were sampled following a standardized sampling protocol. Two batteries of 19 gill-nets with mesh sizes of $8,10,12,14,15,18,20,25,30,35,40,45,50,55,60,65,70$, 75 and $80 \mathrm{~mm}$ were used. Each net measures $30 \mathrm{~m}$ long by $1.5 \mathrm{~m}$ deep. Gill-nets were set 


\section{Table III}

Fish assemblage descriptors tested for relationships with environmental variables. (1: Hocutt et al., 1994; 2: Hay et al., 1996; 3: Hugueny et al., 1996; 4: Kamdem Toham and Teugels 1999; 5: Gooré Bi 2009).

\begin{tabular}{|c|c|c|c|c|}
\hline Type & Name & Code & References & Transformation \\
\hline \multirow[t]{4}{*}{ Global } & Number of native species & NE & $1,2,3,4,5$ & none \\
\hline & Catch per unit effort of natives & CPUE & $1,2,3,4$ & $\log (x)$ \\
\hline & Shannon-Weaver diversity & Isha & 5 & $x^{1,8}$ \\
\hline & Biomass of natives & Biom & 5 & $\log (x)^{2}$ \\
\hline \multirow{7}{*}{$\begin{array}{l}\text { Taxonomic } \\
\text { relative richness }\end{array}$} & Number of benthic species & NEB & 1,2 & none \\
\hline & Number of pelagic species & NEP & 1 & none \\
\hline & $\begin{array}{c}\text { Number of benthic Siluriform } \\
\text { species }\end{array}$ & NEBS & 3,4 & $\operatorname{Rnd}(x+c)$ \\
\hline & Number of Mormyrid species & NEM & 3 & $\operatorname{Rnd}(x)$ \\
\hline & Number of Cichlid species & NEC & 1,3 & none \\
\hline & Number of Cyprinid species & NECy & 4,5 & $\operatorname{Rnd}(x)+c$ \\
\hline & Number of Alestid species & NEA & 4 & none \\
\hline \multirow[t]{5}{*}{$\begin{array}{l}\text { Trophic } \\
\text { relative abundance }\end{array}$} & $\begin{array}{l}\text { Percentage of individual } \\
\text { omnivores }\end{array}$ & OMN & $1,2,3,4,5$ & $\log (x)$ \\
\hline & $\begin{array}{l}\text { Percentage of individual } \\
\text { piscivores }\end{array}$ & PIS & $1,2,3,4,5$ & $\log (x)$ \\
\hline & $\begin{array}{l}\text { Percentage of individual } \\
\text { invertivores }\end{array}$ & INV & $1,2,3,4$ & $\log (x)$ \\
\hline & $\begin{array}{c}\text { Percentage of individual } \\
\text { herbivores }\end{array}$ & HER & 1,2 & $\arcsin (\sqrt{ } x / 100))$ \\
\hline & $\begin{array}{l}\text { Percentage of individual } \\
\text { planktivores }\end{array}$ & PLA & 1,5 & $\log (x)$ \\
\hline
\end{tabular}

parallel to the bank at $1.5 \mathrm{~m}$ depth during high and low water periods. Nets were set overnight (5.00 p.m-7.00 a.m) and during the following day (7.00 a.m-12.00 p.m). Indeed, gill-net selectivity depends on the probability that the fish meets the net and the probability that the fish was caught and retained in the net (a function of the circumference of the fish's head and of the mesh size of the gill-net) (Spangler and Collins, 1992).

Many fish assemblage descriptors were considered as possible index metrics. Each of them are biological indicators. These biological indicators were chosen from a wide variety of trophic levels and taxonomic groups in order to develop a measure of ecosystem health of the Bandama River. Fish assemblage metrics included in the study of Bandama river quality were generally chosen based on pre-existing fish IBI studies in Africa. These metrics were defined by Hocutt et al. (1994), Hay et al. (1996), Hugueny et al. (1996), Kamdem Toham and Teugels (1999), and Gooré Bi (2009) in different African rivers (Table III). Three types of descriptors were computed from the fish assemblage data: global, taxonomic and trophic ones.

The four global descriptors were: number of native species, Catch per unit effort of natives, Biomass of natives (in a defined sample) and The Shannon-Weaver index. These descriptors were supposed to decrease with human perturbations. Fish were identified according to Paugy et al. (2003a, 2003b) at species level. Each fish was counted, measured and weighed. 
The taxonomic descriptors were the relative number of species of major fish families. Taxonomic classification is based on morphological characters and it is likely that form is linked to some aspects of the ecological role of species in the ecosystem (Matthews, 1998). The families considered in the analyses were the Mormyridae, which are sensitive species (Hugueny et al., 1996), the Alestidae, which are active pelagic swimmers (Kamdem Toham and Teugels, 1999), the Cyprinidae, which are species with either mid-water or benthic orientation (Kamdem Toham and Teugels, 1999) and the Cichlidae, species well suited to live in structured edge or vegetated habitats according to Winemiller et al. (1995). Their relatively high species richness and broad geographical distribution (Paugy et al., 2003a, 2003b) also make them useful indicators of ecosystem degradation over a wide range of conditions (Kamdem Toham and Teugels, 1999). The habitat descriptors included the number of benthic species, the number of benthic Siluriform species and the number of pelagic species. These descriptors were heavily influenced by the degradation of habitat components (substrate, width, depth, current, vegetation and general description of the environment) which, according to Bain et al. (2000), was due to the modification of natural flow by the discontinuous and erratic water releases from hydroelectric dams. Benthic Siluriform species unlike benthic species are large and long-lived species. These two habitat descriptors were used in this study because they were mentioned separately in different studies (Table III). The species number also decreases with human perturbation.

Trophic descriptors included specimens whose diet categories were determined from previous stomach content analysis for Bandama species caught in this study (Table III). The diet of species caught with an empty stomach was provided by other authors (Ngouda, 1997; Fishbase, 2003; Paugy and Lévêque, 2006). The trophic categories were piscivores, herbivores (higher plant), invertivores (regrouped insectivores and other benthic invertebrates), phytoplanktivores (algae, plankton) and omnivores (similar proportions of plants and animals). The latter four categories showed a sensitivity to water quality degradation and also habitat degradation (Karr et al., 1986; Kiblut, 2002). In this category, unlike other metrics, the number of omnivores was supposed to increase with human perturbation.

Biological descriptors and environmental variables were transformed to achieve a normal distribution as much as possible (Table II and III).

\section{> SELECTION OF FISH ASSEMBLAGE METRICS AND INDEX DEVELOPMENT}

The selection of fish assemblage metrics is based on Tejerina-Garro et al.'s (2006) method. It proceeded in two steps. Firstly, we computed multilinear regressions between fish assemblage descriptors and environmental variables. To reduce the cases of co-linearity (Oberdorff et al., 1995), we used a forward stepwise selection of the environmental variables combined with a ridge regression. Environmental variables likely to be modified by human disturbances typically encountered were excluded before modeling the relationships between fish descriptors and environment variables of reference samples. In practice, that means excluding the physicochemical parameters (water conductivity and total dissolved solids, dissolved oxygen, $\mathrm{pH}$, water transparency, and temperature).

Secondly, we compared the residuals of preceding relation between a priori separation in the reference stations and disturbed ones using $t$-tests. Residual values of descriptors that displayed statistical differences between the two groups were selected as metrics for inclusion in the final index.

Thirdly, for each metric, we defined the upper and the lower anchors (Hering et al., 2006). The upper and lower anchors mark the indicative range of a metric. We used the standardized residuals as scores. We take a fictive example of an index composed of the metrics: specific richness and \% of individual omnivores. The first metric was supposed to increase with area quality; it is the opposite for the second. So, we multiply the standardized residuals of $\%$ of individual omnivores by $(-1)$. The final index score at each station is the sum of the standardized residuals of metrics selected which have the same weight (the same variance). 


\section{> INTERPRETATION OF THE INDEX}

A tentative interpretation of the index values was made by computing a stepwise forward regression between the metrics selected and the environmental parameters supposed to be directly influenced by various disturbances and not included in the reference models (water conductivity and total dissolved solids, $\mathrm{pH}$, water transparency, and water temperature).

All statistical analyses were performed with the software STATISTICA 7.1.

\section{RESULTS}

The biological characteristics used to calculate the IBI are shown in Table IV. A total of 70 fish species were collected with gill-nets. 16 fish descriptors were analyzed. The descriptors (7) that did not show any significant relationship with environmental variables were the number of native species, Catch per unit effort of natives, Number of Cichlid species, number of Cyprinid species, and the percentage of the omnivore, piscivore and phytoplanktivore individuals (Table V). Simple relationships were detected between environmental variables and other descriptors (9). However, a complex relationship was noted between the flow velocity, distance from source, canopy closure and mixed clay-mud, and the Shannon-Weaver index. The variables that most influenced fish assemblages were: the flow velocity, the distance from source and substrate type. The flow velocity had a positive effect on the number of benthic species, the percentage of herbivores and the Shannon-Weaver index, whereas the effect was negative on the percentage of individual invertivores. The number of benthic Siluriform species, the number of Mormyrids and the Shannon-Weaver index were negatively affected by distance from source.

For 6 fish assemblage descriptors, the mean residuals of the regression between descriptor and habitat were significantly different in the reference and disturbed stations (Table VI). Number of native species, the number of Cichlid species, the percentage of individual invertivores and the biomass were lower in the disturbed samples, whereas the number of benthic Siluriform species and percentage of individual herbivores were higher.

Table VII shows that the supposed disturbed stations exhibited values equal to or lower than 2.84 (mean = -2.58), with the exception of the site B12 (Kimoukro) and the site B18 (Ahua), which showed high values (respectively, 5.14 and 6.38). Although some samples from reference stations showed low index values at the sites B24 (Ouokoukro, -5.65), B25 (Angouakro, -3.40) and B37 (Zoola Danagoro, -6.39), the mean value for reference stations was significantly higher than that of disturbed stations (mean $=1.96 ; t=3.00 ; p<0.05$ ).

Among the environmental variables related to water quality, the physicochemical parameters did not indicate significant change with perturbations (Table VIII). However, the changes observed were not uniform for the different types of perturbation. We noted low variability between the changes. Stations located between the man-made lakes of Kossou and Taabo and stations with gold mining were characterized by low dissolved oxygen. The stations disturbed by urban and/or agricultural diffuse pollution had high values of $\mathrm{pH}$, conductivity, total dissolved solids and temperature. Stations with artisanal gold mining showed low $\mathrm{pH}$ and total dissolved solids, but had high transparency. Conductivity, temperature and transparency were low at stations with industrial effluent. Linear regressions of the sensitive metrics against the physicochemical variables generated few relationships (Table IX). Conductivity had a positive effect on the species and the percentage of individual invertivores. The biomass of natives increases with the $\mathrm{pH}$, whereas the opposite effect was observed for number of benthic Siluriform species.

\section{DISCUSSION}

Monitoring the fish community is a viable alternative to physicochemical monitoring programs for assessment of biotic integrity (Karr, 1981). 
Table IV

Number of fish species collected using gill-nets within Bandama River. 1= marine and/or brackish species; 2 = introduced species; 3 = hybrid.

\begin{tabular}{|c|c|c|c|}
\hline Families & Species & Diet & Habitat \\
\hline Protopteridae & Protopterus annectens & Piscivore & Benthic \\
\hline Polypteridae & Polypterus endlicheri & Piscivore & Benthic \\
\hline Elopidae & Elops lacerta $^{1}$ & Piscivore & Pelagic \\
\hline Clupeidae & Pellonula leonensis & Invertivore & Pelagic \\
\hline Osteoglossidae & Heterotis niloticus $^{2}$ & Herbivore & Benthic \\
\hline Notopteridae & Papyrocranus afer & Invertivore & Benthic \\
\hline \multirow[t]{8}{*}{ Mormyridae } & Marcusenius furcidens & Invertivore & Benthic \\
\hline & Marcusenius senegalensis & Invertivore & Benthic \\
\hline & Marcusenius ussheri & Invertivore & Benthic \\
\hline & Marcusenius sp & Invertivore & Benthic \\
\hline & Mormyrops anguilloides & Piscivore & Benthic \\
\hline & Mormyrus rume & Invertivore & Benthic \\
\hline & Pollimyrus isidori & Invertivore & Benthic \\
\hline & Petrocephalus bovei & Invertivore & Benthic \\
\hline Hepsetidae & Hepsetus odoe & Piscivore & Benthic \\
\hline \multirow[t]{8}{*}{ Alestidae } & Alestes baremoze & Invertivore & Benthopelagic \\
\hline & Brycinus imberi & Herbivore & Benthic \\
\hline & Brycinus longipinnis & Invertivore & Pelagic \\
\hline & Brycinus macrolepidotus & Herbivore & Pelagic \\
\hline & Brycinus nurse & Invertivore & Pelagic \\
\hline & Hydrocynus forskalii & Piscivore & Pelagic \\
\hline & Micralestes elongatus & Invertivore & Pelagic \\
\hline & Micralestes occidentalis & Invertivore & Pelagic \\
\hline Distichodontidae & Distichodus rostratus & Herbivore & Benthic \\
\hline \multirow[t]{9}{*}{\begin{tabular}{|l|} 
Cyprinidae \\
\end{tabular}} & Barbus ablabes & Invertivore & Benthopelagic \\
\hline & Barbus macrops & Invertivore & Benthopelagic \\
\hline & Barbus perince & Invertivore & Benthopelagic \\
\hline & Barbus sublineatus & Invertivore & Benthopelagic \\
\hline & Barbus sp & Invertivore & Benthopelagic \\
\hline & Labeo coubie & Phytoplanktivore & Benthopelagic \\
\hline & Labeo parvus & Phytoplanktivore & Benthopelagic \\
\hline & Labeo sp & Phytoplanktivore & Benthopelagic \\
\hline & Raiamas senegalensis & Invertivore & Benthic \\
\hline
\end{tabular}


Table IV

(Continued).

\begin{tabular}{|c|c|c|c|}
\hline Families & Species & Diet & Habitat \\
\hline \multirow[t]{3}{*}{ Claroteidae } & Auchenoglanis occidentalis & Invertivore & Benthic \\
\hline & Chrysichthys maurus & Invertivore & Benthic \\
\hline & Chrysichthys nigrodigitatus & Invertivore & Benthic \\
\hline \multirow[t]{3}{*}{ Schilbeidae } & Paraillia pelucida & Invertivore & Benthic \\
\hline & Schilbe intermedius & Piscivore & Pelagic \\
\hline & Schilbe mandibularis & Herbivore & Benthic \\
\hline \multirow[t]{3}{*}{ Clariidae } & Clarias anguillaris & Omnivore & Benthic \\
\hline & Heterobranchus isopterus & Invertivore & Benthic \\
\hline & Heterobranchus longifilis & Piscivore & Benthic \\
\hline Malapteruridae & Malapterurus electricus & Piscivore & Benthopelagic \\
\hline \multirow[t]{3}{*}{ Mochokidae } & Synodontis bastiani & Invertivore & Benthopelagic \\
\hline & Synodontis punctifer & Herbivore & Benthopelagic \\
\hline & Synodontis schall & Herbivore & Benthopelagic \\
\hline Channidae & Parachanna obscura & Piscivore & Benthic \\
\hline Centropomidae & Lates niloticus & Piscivore & Benthic \\
\hline \multirow[t]{2}{*}{ Carangidae } & 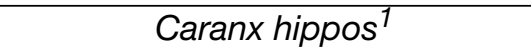 & Invertivore & Pelagic \\
\hline & Trachinotus teraia $^{\top}$ & Invertivore & Pelagic \\
\hline Gerreidae & Gerres melanopterus $^{\top}$ & Invertivore & Benthic \\
\hline \multirow[t]{13}{*}{ Cichlidae } & Chromidotilapia guntheri & Invertivore & Benthopelagic \\
\hline & Hemichromis bimaculatus & Invertivore & Benthopelagic \\
\hline & Hemichromis fasciatus & Piscivore & Benthopelagic \\
\hline & Oreochromis niloticus $^{2}$ & Phytoplanktivore & Benthic \\
\hline & Sarotherodon galilaeus & Phytoplanktivore & Benthic \\
\hline & Sarotherodon melanotheron & Phytoplanktivore & Benthic \\
\hline & Thysochromis ansorgii & Invertivore & Benthopelagic \\
\hline & Tilapia hybride ${ }^{3}$ & Herbivore & Benthopelagic \\
\hline & Tilapia guineensis & Herbivore & Benthopelagic \\
\hline & Tilapia mariae & Herbivore & Benthic \\
\hline & Tilapia zillii & Herbivore & Benthic \\
\hline & Tylochromis jentinki & Invertivore & Benthopelagic \\
\hline & Tilapia sp & Herbivore & Benthopelagic \\
\hline Mugilidae & Liza falcipinnis $^{1}$ & Herbivore & Benthic \\
\hline Polynemidae & Polydactylus quadrifilis $^{\top}$ & Invertivore & Pelagic \\
\hline Gobiidae & Awaous lateristriga & Invertivore & Benthic \\
\hline Eleotridae & Eleotris vittata $^{1}$ & Invertivore & Benthic \\
\hline Anabantidae & Ctenopoma petherici & Invertivore & Benthopelagic \\
\hline Mastacembelidae & mastacembelus nigromarginatus & Invertivore & Benthopelagic \\
\hline 27 & 70 & & \\
\hline
\end{tabular}


Table $V$

Statistics of the linear regressions between descriptors and environmental variables. See Table II for variable codes and definitions.

\begin{tabular}{|c|c|c|}
\hline Descriptor & Variable entered in model (sign of effect) & $p$ \\
\hline \multicolumn{3}{|l|}{ Global } \\
\hline Number of native species & & 0.088 \\
\hline Catch per unit effort of natives & & 0.168 \\
\hline Shannon-Weaver diversity & VEL(+), DistS(-), CAN(-), CM(+) & 0.003 \\
\hline Biomass of natives & $\mathrm{ROC}(-)$ & 0.047 \\
\hline \multicolumn{3}{|l|}{ Taxonomic: relative richness } \\
\hline Number of benthic species & VEL(+), ROC(-) & 0.009 \\
\hline Number of pelagic species & $\operatorname{ALT}(-), \operatorname{GRA}(+)$ & 0.014 \\
\hline Number of benthic Siluriform species & DistS(-) & 0.088 \\
\hline Number of Mormyrid species & DistS(-), WID(+) & 0.081 \\
\hline Number of Cichlid species & & 0.229 \\
\hline Number of Cyprinid species & & 0.073 \\
\hline Number of Alestid species & ALT(-) & 0.025 \\
\hline \multicolumn{3}{|l|}{ Trophic: relative abundance } \\
\hline Percentage of individual omnivores & & 0.227 \\
\hline Percentage of individual piscivores & & 0.191 \\
\hline Percentage of individual invertivores & VEL(-) & 0.097 \\
\hline Percentage of individual herbivores & VEL(+) & 0.023 \\
\hline Percentage of individual planktivores & & 0.251 \\
\hline
\end{tabular}

\section{> FISH-HABITAT RELATIONSHIPS}

Fish assemblages are subject to natural temporal and spatial variability, induced by aquatic habitat variability (Matthews, 1998). Using data from samples of Bandama River stations, relationships between fish assemblages and their habitats were established. The relations we found between fish assemblages and environmental variables were not complex. Indeed, each fish descriptor was associated with only one, two or no variables. We could explain this relation by the homogeneity of the ichthyofauna of Bandama basin, and the weak variations of environmental parameters of tropical rivers. In the downstream area of Konkouré River (Guinea), Hugueny et al. (1996) also noted the homogeneity of ichthyofauna and that no noticeable changes in the assemblages occurred relative to the width of the river. On the Ogun River (Nigeria), like Bandama River (Côte d'Ivoire) and African tropical rivers, the weak slope on a major part of courses could probably favor the homogeneity of fish fauna (Mérona, 1981; Lévêque et al., 1983).

The variables most frequently influenced in the multilinear regressions between habitat and fish assemblage descriptors were those related to river size (flow velocity and distance from source) and diversity of the substrate. The importance of current velocity, river size and substrate in determining fish assemblage composition has been documented by Gorman and Karr (1978) and Hugueny (1990). 
Table VI

Statistics of the comparisons between disturbed and reference samples. Significant differences in bold.

\begin{tabular}{|c|c|c|c|c|c|}
\hline \multirow{2}{*}{\begin{tabular}{|l|} 
\\
Metric \\
\end{tabular}} & \multicolumn{2}{|c|}{ Reference } & \multicolumn{2}{|c|}{ Disturbed } & \multirow[t]{2}{*}{$p$} \\
\hline & Mean & SD & Mean & SD & \\
\hline Number of native species & 3.156524 & 6.118075 & -1.73440 & 6.250246 & 0.042681 \\
\hline Catch per unit effort of natives & 0.631208 & 1.538141 & -0.194153 & 1.150897 & 0.111843 \\
\hline Shannon-Weaver diversity & -2.32344 & 4.399150 & -0.077737 & 3.550182 & 0.213441 \\
\hline Biomass of natives & 8.890879 & 13.44844 & -6.16783 & 13.10449 & 0.005038 \\
\hline \multicolumn{6}{|l|}{ Taxonomic: relative richness } \\
\hline Number of benthic s| & 1.648617 & 3.204865 & 0.779410 & 4.482283 & 0.577013 \\
\hline Number of pelagic species & 0.803368 & 2.528548 & -0.888964 & 2.664577 & 0.109704 \\
\hline Number of benthic Siluriform species & -0.071763 & 1.011049 & 1.125617 & 1.532125 & 0.031869 \\
\hline Number of Mormyrid s & -0.017774 & 1.056152 & -0.060687 & 1.093062 & 0.914266 \\
\hline Number of Cichlid species & 0.734654 & 2.421787 & -1.28950 & 2.245089 & 0.012006 \\
\hline Number of Cyprinid species & 1.558474 & 3.860091 & 0.915689 & 2.351578 & 0.708696 \\
\hline Number of Alestid species & 0.786495 & 1.855279 & -0.898896 & 2.533686 & 0.064850 \\
\hline \multicolumn{6}{|l|}{ Trophic: relative abundance } \\
\hline Percentage of individual omnivores & -0.268955 & 1.929246 & 1.893432 & 2.179941 & 0.080181 \\
\hline Percentage of individual piscivores & 0.533955 & 0.850572 & 0.856133 & 1.128569 & 0.569119 \\
\hline Percentage of individual invertivores & -0.164716 & 0.562687 & -0.672289 & 0.804846 & 0.037091 \\
\hline Percentage of individual herbivores & 0.021813 & 0.243956 & 0.208491 & 0.273368 & 0.037455 \\
\hline ercentage of individual planktivores & 0.623981 & 1.037231 & 1.083230 & 2.258313 & 0.600410 \\
\hline
\end{tabular}

\section{$>$ METRIC SELECTION}

Our metrics were a priori selected from other IBI studies (in Guinea, Cameroon, Namibia and Côte d'Ivoire) which have been proven to identify disturbances (Hocutt et al., 1994; Hay et al., 1996; Hugueny et al., 1996; Kamdem Toham and Teugels, 1999; Gooré Bi, 2009). So, Karr (1981) and Barbour et al. (1995) indicated that fish assemblage metrics including river quality indices were generally chosen on the basis of pre-existing detailed knowledge of fish species ecology in the considered region. For example, in the USA, the taxonomic descriptors of original metrics used by Karr (1981) differ from those used by Oberdorff and Hughes (1992) in France, which are also different from the taxonomic metrics used by Hugueny et al. (1996) in Guinea.

In this study, two general metrics (number of native species and biomass of natives), two taxonomic metrics (number of benthic Siluriform species and number of Cichlid species) and two trophic metrics (percentage of individual invertivores and herbivores) were sensitive to human-caused disturbances.

Number of native species is a common measure of species diversity that generally declines with environmental degradation. However, under certain circumstances (e.g. eutrophication) increasing productivity can lead to an increase in some species in species richness (Oberdorff et al., 2002). In this study, marine hybrid and introduced species were excluded from the total number of species. The observed decrease in richness scores with disturbance was expected. The biomass of natives in our study corresponds to catch per unit effort in weight 


\section{Table VII}

Sample scores (standardized residuals) of individual metrics and total scores for the samples. Samples considered disturbed by human activities are in bold. See Table III for metric codes and definitions.

\begin{tabular}{|c|c|c|c|c|c|c|c|}
\hline \multirow[t]{2}{*}{ Stations } & \multicolumn{6}{|c|}{ Metrics } & \multirow[t]{2}{*}{ Index value } \\
\hline & $\mathrm{NE}$ & NEBS & NEC & INV & HER & Biom & \\
\hline B1 & 1.190584 & 1.744855 & 0.7762334 & -2.373728 & -0.6439469 & 1.159672 & 1.8536695 \\
\hline B2 & & -0.7021708 & -2.001907 & -2.468627 & -0.7428331 & & -5.9155379 \\
\hline B3 & 2.786514 & -1.170584 & 2.35395 & -1.736491 & 1.542441 & 4.892959 & 8.668789 \\
\hline B4 & 1.918601 & 0.456188 & 1.906177 & -1.186751 & 1.741005 & 4.015686 & 8.850906 \\
\hline B5 & 0.9092277 & 0.3390329 & 0.6813745 & 0.6008736 & -0.6181985 & -0.5779465 & 1.3343637 \\
\hline B6 & 0.03081169 & 0.03101731 & -0.5540792 & -0.07278342 & -0.4251382 & 0.1786152 & -0.81155662 \\
\hline$\overline{B 7}$ & -1.231009 & 4.653587 & -1.558758 & -3.985572 & 3.192274 & -5.735866 & -4.665344 \\
\hline B8 & -0.3983835 & 0.04100229 & -0.6929259 & 0.581777 & -0.180327 & 1.490218 & 0.84136089 \\
\hline B9 & 1.205385 & & -0.6066576 & -2.046142 & 2.355656 & -3.315428 & -2.4071866 \\
\hline B10 & -0.261918 & -0.3794027 & 0.1393906 & -0.3502907 & 1.707444 & -0.3877634 & 0.4674598 \\
\hline B11 & 1.817943 & 2.144261 & -1.929868 & -0.5309598 & 1.378809 & -0.07131477 & 2.80887043 \\
\hline B12 & 1.737052 & 7.557501 & 0.02214076 & -5.265246 & -0.2734332 & 1.365959 & 5.14397356 \\
\hline$\overline{B 13}$ & 0.6296821 & & -1.084866 & -9.055643 & 2.296748 & 0.684182 & -6.5298969 \\
\hline B14 & 0.6634292 & & -0.9043868 & -4.916448 & 1.576266 & 1.249109 & -2.3320306 \\
\hline$\overline{B 15}$ & -0.4805373 & & 1.125632 & 2.216768 & -0.7407277 & 3.539117 & 5.660252 \\
\hline$\overline{B 16}$ & 1.068173 & & 0.3316259 & 4.355395 & -2.299216 & 5.36999 & 8.8259679 \\
\hline$\overline{B 17}$ & -1.461328 & & -2.566705 & -5.5752 & 0.4121369 & -0.669431 & -9.8605271 \\
\hline B18 & & & 3.421859 & 2.70947 & 0.2521845 & & 6.3835135 \\
\hline$\overline{B 19}$ & 0.8948634 & & 2.377535 & & & 0.4233131 & 3.6957115 \\
\hline B20 & & 4.609756 & -0.7239074 & -3.028802 & 0.1304202 & & 0.9874668 \\
\hline $\bar{B} 21$ & & -4.161023 & 1.036212 & 2.963035 & -1.628987 & & -1.790763 \\
\hline $\bar{B} 22$ & & & 2.35395 & 0.8898765 & -1.675803 & & 1.5680235 \\
\hline $\bar{B} 23$ & -0.3519365 & 0.02124356 & -1.352706 & -0.6424364 & 0.05635228 & 0.6081482 & -1.66133486 \\
\hline B24 & & & -2.516304 & -6.152859 & 3.017434 & & -5.651729 \\
\hline B25 & & & -1.298139 & -2.295119 & 0.1918524 & & -3.4014056 \\
\hline B26 & 1.019166 & 0.4020934 & 1.548013 & 0.5140415 & -1.130099 & \begin{tabular}{|l|}
-0.6391588 \\
\end{tabular} & 1.7140561 \\
\hline $\bar{B} 27$ & -0.152982 & 2.600667 & & & 2.919198 & -0.9617008 & 4.4051822 \\
\hline B28 & -0.00021242 & -0.4898148 & -0.3725538 & -0.1167913 & -0.03350415 & 0.08891997 & -0.9239565 \\
\hline B29 & & & 3.485088 & & & & 3.485088 \\
\hline $\bar{B} 30$ & -2.595132 & 1.218322 & 1.607902 & 0.1520512 & 0.6946089 & -1.591479 & -0.5137269 \\
\hline B31 & 1.269469 & & 1.360569 & -3.077122 & 1.248601 & 1.668219 & 2.469736 \\
\hline B32 & & 1.865108 & -4.634628 & -4.100413 & & & -6.869933 \\
\hline B33 & -1.645346 & 4.858764 & & & 0.0515078 & \begin{tabular}{|l|}
-0.4236446 \\
\end{tabular} & 2.8412812 \\
\hline B34 & -2.635063 & 0.3050688 & -1.161423 & -2.942014 & 2.711485 & -4.200542 & -7.9224882 \\
\hline B35 & -2.243878 & -1.423249 & -2.686967 & -0.7755076 & -0.09471405 & -4.085454 & -11.3097697 \\
\hline B36 & -0.9467549 & 0.03482833 & 0.6034867 & -0.5143904 & 0.6234705 & -0.7610328 & -0.96039257 \\
\hline B37 & & & -3.521949 & -4.00689 & 1.129615 & & -6.399224 \\
\hline B38 & & -1.758446 & 0.1047063 & -1.065727 & -0.4884034 & & -3.2078701 \\
\hline B39 & 2.328032 & & 1.524428 & & & 3.296029 & 7.148489 \\
\hline B40 & -1.032255 & 1.184121 & -1.43618 & -11.90315 & 6.002004 & -1.143289 & -8.328749 \\
\hline
\end{tabular}


Table VIII

Comparison of selected water quality parameters in reference and disturbed samples.

\begin{tabular}{|l|c|c|c|c|c|c|}
\hline & & & \multicolumn{4}{|c|}{ Type of perturbation } \\
\hline Sample variable & $\begin{array}{c}\text { Reference } \\
(22)\end{array}$ & Disturbed (18) & $\begin{array}{c}\text { Between } \\
\text { dams (9) }\end{array}$ & $\begin{array}{c}\text { Gold mining } \\
(2)\end{array}$ & Diffuse (15) & $\begin{array}{c}\text { Indus. efflu } \\
(4)\end{array}$ \\
\hline pH & \multicolumn{2}{|c|}{ Mean (SD) } & \multicolumn{4}{|c|}{ Range } \\
\hline Dissolved oxygen & $7.40(0.75)$ & $7.57(1.01)$ & $6.89-8.14$ & $6.89-7.13$ & $6.71-10.45$ & $6.92-9.84$ \\
\hline Conductivity & $5.58(1.23)$ & $5.84(0.55)$ & $4.84-6.14$ & $4.84-6.4$ & $5.3-6.73$ & 5.69 \\
\hline Total dissolved solids & $52.51(25.37)$ & $44.44(20.52)$ & $29.66-45.9$ & $30-39.9$ & $29.66-118$ & $36.95-39.66$ \\
\hline Water temperature & $27.70(2.22)$ & $28.38(1.72)$ & $27-30.45$ & 27.95 & $26.25-32.4$ & $26.25-26.93$ \\
\hline Water tranparency & $62.32(52.25)$ & $94.69(56.01)$ & $50-213$ & $130-148$ & $22.5-213$ & $38-65$ \\
\hline
\end{tabular}

No significant difference $(p>0.05)$.

\section{Table IX}

Statistics of the linear regressions between the metrics composing the index and physicochemical variables. See Table II for codes and definitions. Significant regressions at $p<0.05$ are in bold.

\begin{tabular}{|l|c|c|}
\hline Descriptor & Relation (sign of effect) & $p$ \\
\hline Number of native species & $\mathrm{Cnd}(+)$ & 0,019 \\
\hline Biomass of natives & $\mathrm{pH}(+)$ & 0,002 \\
\hline Number of benthic Siluriform species & $\mathrm{pH}(-)$ & 0,036 \\
\hline Number of Cichlid species & (no variable in equation) & \\
\hline Percentage of individual invertivores & $\mathrm{Cnd}(+)$ & 0,025 \\
\hline Percentage of individual herbivores & $\mathrm{pH}(-)$ & 0,062 \\
\hline
\end{tabular}

of native fish species in each stretch. The difference in biomass of natives can result from differences in fish weight. Indeed, fish weight is high when the coefficient of condition which reflects the fish plumpness is high in areas with abundant food (Kartas and Quignard, 1984; Gooré $\mathrm{Bi}, 2009)$. But also, the difference in biomass could result in fish abundance and difference in fish composition. It could be explained by the behavior of fish reproduction, which may be altered by a reduction in spawning areas in a river. In the long term, the changes in the hydrological regime can influence the dynamics of fish populations by influencing the processes of reproduction and recruitment, leading to change in the relative abundance of species (de Lafontaine et al., 2002). This metric, not included in the original metric defined by Karr (1981), was sensitive to disturbance in our study and showed significant decrease with perturbation.

Concerning the two taxonomic metrics, we noted that the numbers of benthic Siluriform species showed a significant increase in relative species with perturbation, whereas the family of Cichlidae showed a significant decrease. The benthic Siluriform species was proposed by Oberdorff and Hughes (1992) and Hugueny et al. (1996) as a replacement for the original metric of Karr (1981), number of sucker species. In general, these benthic Siluriform species are large and long-lived species associated with the river bottom. They are opportunist predators in general, with trends to invertivory, eating aquatic insects (chironomids), mollusks, crustaceans and annelids, but also fish, aquatic plants and detritus (Lévêque and Paugy, 2006). This feeding habit favors this family in disturbed environments. Certain species of this 
taxonomic group (e.g. Clarias) are known for their varied tolerance to pollution and habitat degradation (Moreau, 1988; Lévêque and Paugy, 2006). The ability to use other food resources when available, and to take advantage of ambient oxygen when the dissolved oxygen supply becomes scarce, frees these species from prey scarcity and hypoxia conditions caused by water quality disturbances.

The Cichlidae family reacted to disturbances with a decrease in number of species. Fausch et al. (1984) suggested that in tropical zones, this metric replaces the number of sunfish species proposed by Karr (1981), keeping its intent of measuring the degree of degradation of submerged vegetation. The Cichlidae were used as a metric by Hocutt et al. (1994) and Hugueny et al. (1996) in African rivers.

The percentage of individual invertivores decreases significantly with perturbation. The diet of aquatic invertivores is based on benthic invertebrates, which are affected by human-induced disturbance such as substrate modification, flow regulation or sewage (Statzner et al., 2001). This metric is a surrogate for evaluating the degree that the invertebrate assemblage is degraded by environmental changes (Oberdorff et al., 2002). The percentage of individual herbivores is to assess the quality of the aquatic system food base at the primary level. Also, a large number of species prefer vegetated areas (Hocutt et al., 1994; Hay et al., 1996). Conversely, in our study, we found that the herbivores were reacting to disturbance with an increase in the percentage of individuals. In general, we noted that excessive intake of nutrients increases the production of algae and aquatic plants. This massive production of plants would also favor an increase in individuals which are herbivores in these disturbed environments. Indeed, direct observation in the field led us to suspect the existence of episodic pollution incidents. However, in the absence of any specific chemical analysis of the water, it was impossible to identify nutritive substances.

The percentage of individual herbivores was not included in the original metrics of Karr (1981). Due to the method we used to select metrics, separation of disturbed and reference samples should be good if not perfect. However, some samples called reference samples had values comparable with those called disturbed. There are various reasons for this result. Firstly, the index integrates 6 metrics, which should react differently to different disturbances. We also noted, among our metrics, the absence of an important metric: proportion of (in) tolerant species and/or individuals. This metric is often used and generally very efficient (Karr et al., 1986; Oberdorff and Hughes, 1992; Kamdem Toham and Teugels, 1999; Kestemont et al., 2000). Unfortunately, the necessary knowledge to identify all species and to integrate this metric is still limited in Africa, which would surely harm index quality. Secondly, the classification of our sites into disturbed and reference could have been erroneous in some cases. For example, the site B18, in the downstream area of the river, was considered disturbed because of the presence of many fishermen and agricultural diffuse pollution (hevea, cocoa, palm oil field), but it receives a high index score. The site B12 also receives a high score. Its location (between both man-made lakes, but a little further from the Taabo lake) makes it less sensitive to water level variation.

\section{> INTERPRETATION OF INDEX VARIABILITY WITH PHYSICOCHEMICAL PARAMETERS}

Although the small number of samples precludes a statistical analysis of the changes in physicochemical parameters, in the disturbed sites relative to the origin of the perturbation, some trends were revealed by the data. Artisanal gold mining on stations located between both dams (Kossou and Taabo) could be the cause of the low dissolved oxygen. According to Marteau (2001), the technique to extract gold consists of removing large amounts of soil for separation of the precious metal which, in turn, lowers endogenous oxygen production. The high $\mathrm{pH}$, conductivity, total dissolved solids, transparency and temperature at urban and/or agricultural diffuse pollution stations were probably related to their particular hydrodynamics because these flows were possibly affected by the transit of persons and merchandise, and also by extensive fisheries. Consequently, the flow is considerably reduced in the mid-course, a situation which favors sedimentation according to Tejerina-Garro et al. (2006). Stations 
disturbed by industrial effluents had low conductivity, temperature and transparency. Direct information in the field led us to suspect the existence of episodic pollution incidents. The result is the incorporation of large quantities of suspended material in the rivers, which decreases transparency (Tejerina-Garro et al., 2006) and increases pH (Hugueny et al., 1996). The number of relative species and percentage of individual invertivores were positively related to conductivity. Da Costa et al. (2000) found that conductivity was also amongst the main discriminant factors in both Agnebi and Bia rivers. However, we did not detect any difference in this parameter between disturbed and reference samples, but the conductivity was higher in stations affected by urban and/or agricultural diffuse pollution.

Benthic Siluriform species were negatively related to $\mathrm{pH}$, and the biomass of natives was positively related to $\mathrm{pH}$, while its influence on individual herbivores was not significant. $\mathrm{pH}$ was higher in stations affected by industrial effluents and urban and/or agricultural diffuse pollution, and it also did not show any difference between disturbed and reference samples. However, we noted that Yao et al. (2005) found a significant relationship between species number and pH in the Comoé River, but Da Costa et al. (2000) noted that the pH had the slightest influence on the ordination of samples in both Agnebi and Bia rivers.

The last relationship observed was that no physicochemical variable was influenced by Cichlid species. Indeed, a number of Cichlid genera are widespread in Africa, e.g. Tilapia species are continuously found throughout Africa from the eastern Cape in South Africa to Senegal in the west and the Nile and beyond to the Middle East in the east (Skelton, 1988).

However, additional research is needed to determine if FIBI scores only generated by one gear type can be used interchangeably with those generated by another gear type (e.g., electrofishing boat versus paired fyke nets). A fish-based index is a tool that can be used for water course condition assessment, and while it can produce rapid assessments, it should also be used in the man-made lakes of Bandama Basin in order to measure strong responses to human disturbance. It should also be noted that FIBI scores are not a measure of the intensity of pressures. However, it is necessary to determine a pressure gradient in the basin. Nevertheless, the Fish Index should prove to be an effective tool to aid in the management and protection of important fish habitats in the riverine ecosystem of the Bandama River.

\section{ACKNOWLEDGEMENTS}

This work forms part of a project entitled "Développement d'un indice d'intégrité piscicole pour la préservation de la biodiversité du fleuve Bandama (Côte d'lvoire)" financed by the "Centre Suisse de Recherche Scientifique (CSRS)" through the "Programme d'Appui Stratégique à la Recherche Scientifique (PASRES)" and the state of Côte d'Ivoire. The authors thank the researchers, students and technical staff who took part in the data-gathering. They are very grateful to Bernard Hugueny for his in-depth analysis of the manuscript and useful comments, and Mr. N'Guessan for his careful reading of this manuscript.

\section{REFERENCES}

Aboua B.R.D., N'Zi K.G., Kouamélan E.P., Berté S. and Bamba M., 2010. Organisation spatiale du peuplement de poissons dans le Bandama. International Journal of Biological and Chemical Sciences, 4, 1480-1493.

Allan J.D. and Flecker A.S., 1993. Biodiversity conservation in running waters: identifying the major factors that threaten destruction of riverine species and ecosystems. BioScience, 43, 32-43.

Bain M.B., Harigb A.L., Loucksc D.P., Goforthd R.R. and Millsa K.E., 2000. Aquatic ecosystem protection and restoration: advances in methods for assessment and evaluation. Environ. Sci. Pol., 3, 589-598.

Barbour M.T., Stribling J.B. and Karr J.R., 1995. Multimetric approach for establishing biocriteria and measuring biological condition. In: Davis W.S. and Simon T.P. (eds.), Biological assessment and criteria, Tools for water resource planning and decision making, Lewis Publ., London, 63-77. 
Berté S., 2009. Biologie et écologie de Distichodus rostratus (Günther, 1864) dans un hydrosystème particulier en Côte d'Ivoire, Thèse de Doctorat à I'Université de Cocody-Abidjan, Côte d'Ivoire, $180 \mathrm{p}$.

Da Costa K.S., Gourène G., Tito De Morais L. and Thys Van Den Audenaerde D.F.E., 2000. Caractérisation des peuplements ichtyologiques de deux fleuves côtiers Ouest-Africains soumis à des aménagements hydroagricoles et hydroélectriques. Vie et Milieu, 50, 65-77.

Daget J. and IItis A., 1965. Poissons de Côte d'Ivoire (eaux douces et saumâtres), Mémoires de l'Institut Fondamental de l'Afrique Noire, 74, 385 p.

de Lafontaine Y., Marchand F., Labonté D. and Lagacé M., 2002. The Hydrological Regime and Fish Distribution and Abundance in the St. Lawrence River: Are Experimental Trap Data a Valid Indicator? Environnement Canada - Région du Québec, Conservation de l'environnement, Centre Saint-Laurent, Rapport scientifique remis à la Commission mixte internationale, 33 p.

Fausch K.D., Karr J.R. and Yant P.R., 1984. Regional application of an index of biotic integrity based on stream fish communities, Trans. Am. Fish. Soc., 112, 39-55.

Fishbase, 2003. Fish species in Bandama River rises as the white Bandama in the Northern highlands and flows southward to enter the gulf of Guinea and the Tagba Lagoon near Grand-Lahou. Its majors tributaries are the Red Bandama (Marahoué) and the N'Zi, Fishbase.org. http://fish.mongabay.com/data/ecosystems/Bandama River.htm.

Gooré Bi G., 2009. Impact des activités humaines sur les communautés de poisson dans les systèmes aquatiques de la zone côtière ivoirienne (Côte d'Ivoire) : Établissement d'un indice d'intégrité biotique (IIB), Thèse de doctorat, Université de Cocody-Abidjan, Côte d'Ivoire.

Gorman O.T. and Karr J.R., 1978. Habitat structure and stream fish communities. Ecology, 59, 507-515.

Gourène G., Teugels G.G., Hugueny B. and Thys Van Den Audenaerde D.F.E., 1999. Évaluation de la diversité ichtyologique d'un bassin ouest-africain après la construction d'un barrage. Cybium, 23, 147-160.

Hay C.J., Van Zyl B.J. and Steyn G.J., 1996. A quantitative assessment of the biotic integrity of the Okavongo river, Namibia, based on fish. Water South Africa, 22, 263-284.

Hering D., Feld C.K., Moog O. and Ofenbock T., 2006. Cook book for the development of a Multimetric Index for biological condition of aquatic ecosystems: Experiences from the European AQEM and STAR projects and related initiatives. Hydrobiologia, 566, 311-324.

Hocutt C.H., Johnson P.N., Hay C. and Van Zyl B.J., 1994. Biological basis of water quality assessment: the Kavango River, Namibia. Revue d'Hydrobiologie Tropicale, 27, 361-384.

Hugueny B., 1990. Richesse des peuplements de poissons dans le Niandan (Haut Niger, Afrique) en fonction de la taille de la rivière et de la diversité du milieu. Revue d'Hydrobiologie Tropicale, 23, 351-364.

Hugueny B., Camara S., Samoura B. and Magassouba M., 1996. Applying an index of biotic integrity based on fish assemblages in a West African river. Hydrobiologia, 331, 71-78.

Kamdem Toham A. and Teugels G.G., 1999. First data on an index of biotic integrity (IBI) based on fish assemblages for the assessment of the impact of deforestation in a tropical West African river system. Hydrobiologia, 397, 29-38.

Karr J.R., 1981. Assessing of biotic integrity using fish communities. Fisheries, 6, 21-27.

Karr J.R., Fausch K.D., Angermeier P.L., Yant P.R. and Schlosser I.J., 1986. Assessing biological integrity in running waters. A method and its rationale. Illinois Natural History Survey, Special Publication 5, 1-28.

Kartas F. and Quignard J.P., 1984. La fécondité des poissons téléostéens, Masson, Collection biologique des milieux marins 5, $117 \mathrm{p}$.

Kestemont P., Didier J., Depiereux E. and Micha J.C., 2000. Selecting ichtyological metrics to assess river bassin ecological quality. Arch. Hydrobiol., 121, 673-687.

Kiblut K., 2002. Les communautés ichtyologiques et mesure de l'indice d'intégrité biotique du bassin versant de la rivière Kamouraska, Diplôme d'études supérieures spécialisées « ingénierie des hydrosystèmes continentaux en Europe », Université François Rabelais, Tours, France, 64 p.

Koné T., Teugels G.G., N'Douba V., Gooré Bi G. and Kouamélan E.P., 2003. Premières données sur l'inventaire et la distribution de l'ichtyofaune d'un petit bassin côtier ouest-africain : Rivière Gô (Côte d'Ivoire). Cybium, 27, 101-106.

Kouamé K.A., Yao S.S., Gooré Bi G., Kouamélan E.P., N’Douba V. and Kouassi N.J., 2008. Influential environmental gradients and patterns of fish assemblages in a West African basin. Hydrobiologia, 603, 159-169.

Kouamélan E.P., 1999. L'effet du lac de barrage d'Ayamé (Côte d'Ivoire) sur la distribution et l'écologie alimentaire des poissons Mormyridae (Teleostei, Osteoglossiformes), Thèse de Doctorat. Katholieke Universiteit Leuven, Belgique, $221 \mathrm{p}$.

Kouamélan E.P., Teugels G.G., N'Douba V., Gooré Bi G. and Koné T., 2003. Fish diversity and its relationship with environment variables in West African basin. Hydrobiologia, 505, 139-146. 
Lévêque C. and Paugy D., 1999. Les poissons des eaux continentales africaines : diversité, écologie, utilisation par l'homme, IRD, Éditions, Paris, $521 \mathrm{p}$.

Lévêque C., Dejoux C. and Iltis A., 1983. Limnologie du fleuve Bandama, Côte d'Ivoire. Hydrobiologia, $100,113-141$

Marteau P., 2001. Mines et Carrières. In: Barret J. (ed.), Atlas illustré de la Guyane, CNES, IESG, IRD, Région Guyane Publ., 90-93.

Matthews W.J., 1998. Patterns in freshwater fish ecology, Chapman \& Hall, New York.

McMahon T.E., Zale A.V. and Orth D.J., 1996. Aquatic habitat measurements. In: Murphy B.R. and Willis D.W. (eds.), Fisheries Techniques, American Fisheries Society, Bethesda, Maryland, USA, 83-120.

Mérona B. de, 1981. Zonation ichtyologique du bassin du Bandama. Revue d'Hydrobiologie Tropicale, $14,63-75$.

Moreau Y., 1988. Physiologie de la respiration. In: Lévêque C., Bruton M.N. and Ssenlengo G.W (eds.), Biologie et écologie des poissons d'eau douce africains, Paris, France, 113-135.

Natajaran A.V. and Jhingran A.G., 1961. Index of preponderance - a method of grading the food elements in the stomach of fishes. Indian Journal of Fisheries, 8, 54-59.

Ngouda S., 1997. Contribution à l'étude qualitative du régime alimentaire de quelques espèces de poisons dans l'estuaire du Sine-Saloum (Sénégal), Centre de recherche océanographique de Dakar-Thiaroye, Sénégal, $38 \mathrm{p}$.

Oberdorff T. and Hughes R.M., 1992. Modification of an index of biotic integrity based on fish assemblages to characterize rivers of the Seine Basin, France. Hydrobiologia, 228, 117-130.

Oberdorff T., Guégan J.-F. and Hugueny B., 1995. Global scale patterns of fish species richness in rivers. Ecography, 18, 345-352.

Oberdorff T., Pont D., Hugueny B. and Porcher J.-P., 2002. Development and validation of a fish-based index (FBI) for the assessment of "river health" in France. Freshw. Biol., 47, 1720-1734.

Paugy D., 1994. Écologie des poisons tropicaux d'un cours d'eau temporaire (Baoulé, Haut bassin du Sénégal au Mali) : adaptation au milieu et plasticité du régime alimentaire. Revue d'Hydrobiologie Tropicale, 27, 157-172.

Paugy D. and Lévêque C., 2006. Régimes alimentaires et réseaux trophiques. In: Lévêque C., Paugy D. (eds.), Les poissons des eaux continentales africaines: diversité, écologie, utilisation par l'homme, IRD, Paris, 191-215.

Paugy D., Lévêque C. and Teugels G.G., 2003a. The fresh and brackish water fishes of West Africa, Collection tropical Fauna and Flora, Tome I, IRD Editions, MRAC, Tervuren.

Paugy D., Lévêque C. and Teugels G.G., 2003b. The fresh and brackish water fishes of West Africa, Collection tropical Fauna and Flora, Tome II, IRD Editions, MRAC, Tervuren.

Planquette R. and Lemasson J., 1975. Le peuplement de poissons du Bandama blanc en pays Baoulé. Annales de l'Université Abidjan E 8, 77-121.

Skelton P.H., 1988. Répartition des poissons d'eau douce africains. In: Lévêque C., Bruton M.N. and Ssentongo G.W. (eds.), Biologie et écologie des poissons d'eau douce africains, Travaux et Documents ORSTOM, 216, 65-91.

Spangler G.R. and Collins J.J., 1992. Lake Huron fish community structure based on gill-net catches corrected for selectivity and encounter probability. N. Amer. J. Fish. Manage., 12, 585-597.

Statzner B., Bis B., Doledec S. and Usseglio-Polatera P., 2001. Perspectives for biomonitoring at large spatial scales: a unified measure for the functional composition on invertebrate communities in European running waters. Bas. Appl. Ecol., 2, 73-85.

Tachet H., Richoux P., Bournaud M. and Usseglio-Polatera P., 2006. Invertébrés d'eau douce : systématique, biologie, écologie, CNRS $2^{\mathrm{e}}$ éditions, Paris.

Tejerina-Garro F.L., de Mérona B., Oberdorff T. and Hugueny B., 2006. A fish-based index of large river quality for French Guiana (South America): method and preliminary results. Aquat. Living Resour., 19, 31-46.

Teugels G.G., Lévêque C., Paugy D. and Traoré K., 1988. Etat des connaissances sur la faune ichtyologique des bassins côtiers de Côte d'Ivoire et de l'ouest du Ghana. Revue d'Hydrobiologie Tropicale, 21, 221-237.

Traoré K., 1996. État des connaissances sur les pêcheries continentales ivoiriennes, Rapport de consultation, Projet FAO TCP/IVC/4553, IDESSA, Bouaké, Côte d'Ivoire.

Winemiller K.O., Kelso-Winemiller L.C. and Brenkert A., 1995. Ecomorphological diversification and convergence in fluvial cichlid fishes. Environ. Biol. Fish., 44, 235-261.

Yao S.S., Kouamélan E.P., Kone T., N'Douba V., Gooré Bi G., Ollevier F. and Thys Van Den Audenaerde D.F.E., 2005. Fish communities along environment gradients within the Comoé River basin, Côte d'Ivoire. African Journal of Aquatic Science, 30, 195-204. 